\title{
ANALISIS KINERJA WEBSITE PEMERINTAH KOTA PEKALONGAN
}

\author{
Mohammad Reza Maulana ${ }^{1)}$, Eko Budi Susanto ${ }^{2)}$, Sattriedi Wahyu Binabar ${ }^{3)}$ \\ STMIK Widya Pratama Pekalongan \\ Email : ${ }^{1}$ reza.stmikwp@gmail.com, ${ }^{2}$ eqo_bs@yahoo.com, ${ }^{3}$ binabars@gmail.com
}

\begin{abstract}
The Pekalongan City Government has an official website as a form of service to the community. Website is one form of implementation of E-Government. Website maintenance and repair needs to be done regularly to improve services to the community. There are so many visitors, of course, it becomes a problem when simultaneously accessing a website. For this reason, it is necessary to carry out a work analysis from the Pekalongan City Government website. In analyzing the Pekalongan City Government website, this study used performance testing especially using load testing with several variables including Internet speed, threads (virtual users), ramp-up period, repetition. The tool used to perform the analysis is JMeter. The results of the tests carried out are: for an access speed of $1.8 \mathrm{MBps}$, the server can only serve about 16.8 requests every minute. This of course can cause the website to go down which ultimately cannot be accessed when visited by many visitors.
\end{abstract}

Keywords: Performance testing, load testing, JMeter.

\section{PENDAHULUAN}

Pemerintah Kota Pekalongan memiliki website resmi yang digunakan untuk memberikan informasi kepada masyarakat. Website merupakan salah satu bentuk implementasi dari E-Government yang merupakan sarana interaksi antara masyarakat dengan pemerintah dalam mempermudah layanan elektronik. Banyaknya pengunjung setiap harinya tentunya menjadi tantangan tersendiri bagi pengelola website. Penurunan kemampuan website seperti respon yang lambat yang disebabkan karena peningkatan jumlah pengguna aktif, merupakan masalah serius harus dapat diantisipasi. Website merupakan salah satu layanan informasi yang saat ini banyak diakses oleh pengguna. Dari hal ini harus dipastikan bahwa website dapat bekerja dengan optimal. Website yang baik mampu menangai permintaan dari banyak pengguna (MZ, 2016).

Dalam siklus hidup pengembangan software, salah satu tahapan yang harus dijalankan adalah pengujian. Pada tahapan pengujian sistem, pengujian dapat melibatkan pengguna untuk mengetahui apakah sistem yang telah dibangun telah sesuai dengan kebutuhan (Lee-Jayaram, Berg, Sy, \& Hara, 2019), (Hai-Jew, 2019). Website yang baik tentunya telah melewati tahapan ini. Ada metode pengujian untuk menguji website, salah satu di antaranya adalah pengujian kinerja atau performance testing. Tujuan dari pengujian ini untuk mengetahui kinerja dari sebuah website terhadap tekanan kinerja ketika banyak pengguna atau pengunjung yang mengakses website tersebut (Putri, Hadi, \& Ramdani, 2017).

Pada penelitian sebelumnya telah dilakukan pengujian kecepatan akses menggunakan GTMetrix terhadap website milik Pemerintah Kabupaten Batang (Maulana, Susanto, \& Binabar, 2020). Putri dalam penelitiannya telah melakukan pengujian kinerja pada website penerimaan mahasiswa baru Universitas Brawijaya (Putri, Hadi, \& Ramdani, 2017). Pengujian 
kecepatan akses Sistem Informasi Kegiatan Sekolah berbasis mobile web juga pernah dilakukan (Ghaffur \& Nurkhamid, 2017).

Salah satu teknik atau metode pada pengujian kinerja (performance testing) yaitu: load testing. Sistem diukur dalam berbagai kondisi beban (load condition). Ada berbagi alat yang digunakan untuk melakukan load testing (pengujian beban) dari sebuah website, di antarnya: Apache JMeter, Microsoft Visual Studio (TFS), LoadRunner, Siege. Menurut Rabiya Abbas, di antara alat tersebut Apache JMeter merupakan alat terbaik dalam menganalisis kinerja dari sebuah website (Abbas, Sultan, \& Bhatti, 2017).

Pengujian beban yang dilakukan bertujuan mengukur kinerja website Pemerintah Kota Pekalongan dalam melayani permintaan dengan jumlah pengguna yang banyak dalam waktu yang hampir bersamaan dan website tetap berjalan stabil. Dari hasil pengujian yang dilakukan dapat menjadi rekomendasi pengembangan selanjutnya bagi pihak terkait, sehingga pelayanan akses website ke pengguna (masyarakat) menjadi lebih baik lagi. Untuk itu pada penelitian ini akan dilakukan load testing (pengujian beban) untuk menguji kinerja (performance testing) pada website Pemerintah Kota Pekalongan dengan menggunakan Apache JMeter.

\section{TINJAUAN PUSTAKA}

\subsection{Apache JMeter}

Apache JMeter merupakan "open-source testing tool" yang digunakan untuk melakukan proses pengujian kinerja dari sebuah website. Hal ini berarti dapat digunakan oleh siapapun tanpa harus membayar lisensi. Apache JMeter dikembangkan oleh Apache Software Foundation (ASF). Fungsi utama JMeter adalah mengakses klien/server uji. Selain itu, JMeter digunakan dalam pengujian regresi dengan menghasilkan skrip pengujian. JMeter menyediakan pelaporan offline dari hasil pengujian yang dilakukan (Abbas, Sultan, \& Bhatti, 2017). JMeter dapat digunakan untuk menganalisis dan mengukur kinerja aplikasi web atau jangkauan layanan. JMeter dapat mengetahui kinerja dari sebuah website terhadap tekanan kinerja ketika banyak pengguna atau pengunjung yang mengakses website. JMeter awalnya digunakan untuk menguji aplikasi web atau aplikasi FTP, dalam perkembangannya JMeter juga dapat menguji fungsionalitas server database.

\subsection{Performance Testing}

Salah satu jenis pengujian adalah Performance Testing, yaitu pengujian untuk mengukur kecepatan atau efektivitas, program jaringan komputer, perangkat lunak atau perangkat keras (Patil \& Joshi, 2012). Tujuan utamanya adalah menguji skalabilitas, ketersediaan, dan kinerja berdasarkan sudut pandang perangkat lunak (Bhatti \& Kumari, 2015). Performance Testing memiliki berbagai jenis di antarannya: Load Testing, Stress Testing, Endurance Testing, Spike Testing, Configuration Testing, Isolation Testing.

\subsection{Load Testing}

Load Testing merupakan bagian dari pengujian kinerja (performance testing) pada website. Sistem respon sistem diukur dalam berbagai kondisi beban yang berbeda (Permatasari, et al., 2020). Load testing mengukur kinerja website terhadap tekanan kinerja ketika banyak pengguna atau pengunjung yang mengakses website secara bersamaan. Metode ini menggantikan pengujian dengan cara mengundang banyak pengguna untuk mengakses sebuah website.

\subsection{Kerangka Pikir}

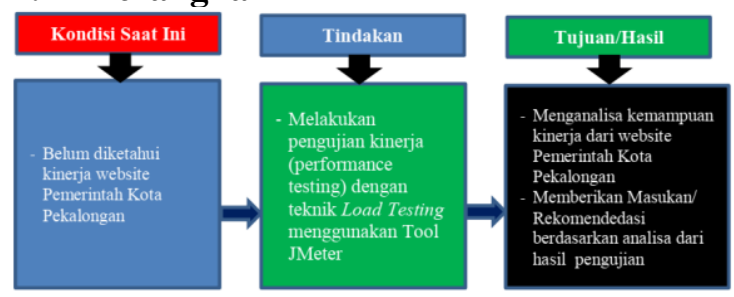

Gambar 1 Kerangka Pikir

Gambar 1 merupakan kerangka pikir dari penelitian yang dilakukan. Pada kondisi awal, peneliti belum menemukan adanya pengujian kinerja website Pemerintah Kota Pekalongan baik melalui publikasi di jurnal maupun lainnya. Setelah itu dilakukan tindakan penelitian melalui tahapan-tahapan 
yang ditentukan untuk melakukan pengujian kinerja/performa dari website Pemerintah Kota Pekalongan. Dari pengujian yang dilakukan akan mendapatkan hasil kemampuan kinerja website yang dapat digunakan sebagai bahan pertimbangan atau rekomendasi untuk pengembangan website kedepannya.

\section{METODE PENELITIAN}

Tahapan penelitian ditentukan terlebih dahulu agar tujuan dari penelitian ini dapat tercapai. Metode yang dilakukan yaitu metode eksperimen dengan kegiatan sebagai berikut (Gambar 2) : (1) Pengumpulan Data dan Persiapan, (2) Penentuan Alat dan Variabel Pengujian, (3) Pengujian Performa Website, dan (4) Analisis Data Performa Website

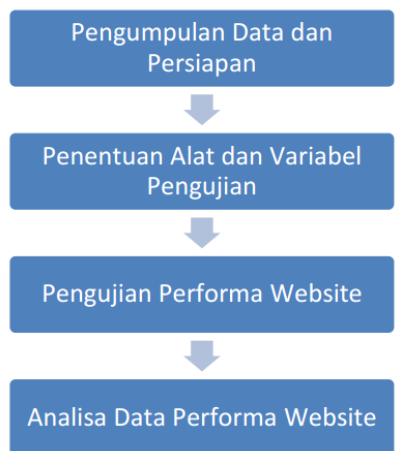

Gambar 2 Rancangan Kegiatan

Pada tahap pengumpulan data, kegiatan yang dilakukan yaitu: mencari alamat website Pemerintah Kota Pekalongan dan melakukan uji coba pada link yang tersedia pada website. Selanjutnya penentuan alat yang digunakan untuk menguji kinerja website yaitu dengan menggunakan aplikasi JMeter dengan jenis pengujian beban akses (load testing) dan menentukan nilai variabel parameter yang ada. Kemudian pengujian terhadap website Pemerintah Kota Pekalongan dilakukan dengan menggunakan JMeter. Pengujian dilakukan dengan cara melakukan beberapa pengaturan seperti HTTP request, jumlah thread dan lainnya ke dalam inputan yang tersedia pada JMeter dan hasil pengujian dicatat. Setelah itu, Tahap terakhir yaitu melakukan analisis dari hasil pengujian yang telah dilakukan dengan teknik analisis deskriptif .

\section{HASIL DAN PEMBAHASAN}

4.1 Pengumpulan Data

Website yang akan diuji yaitu website utama milik Pemerintah Kota Pekalongan dengan alamat https://pekalongankota.go.id/. Setelah dilakukan pengecekan, website Pemerintah Kota Pekalongan tersebut dapat diakses melalui smartphone ataupun komputer. Pengecekan tersebut dilakukan dalam rentang waktu dari tanggal 21 Juli 2021 sampai dengan 25 Juli 2021. Selanjutnya halaman yang akan diuji pada website tersebut adalah halaman beranda, karena halaman beranda yang pertama kali muncul ketika diakses oleh pengguna. Halaman beranda ini yang akan dijadikan sebagai halaman pengujian load testing.

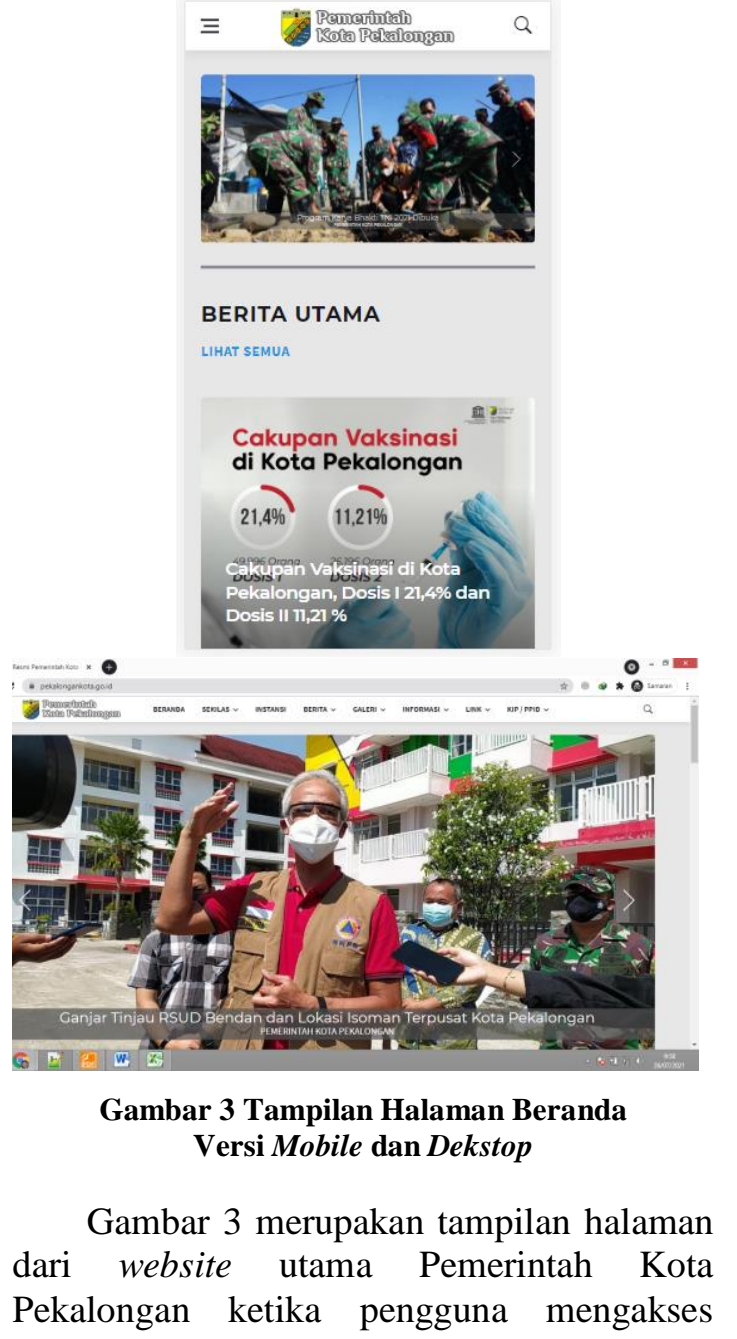


melalui perangkat komputer di layar monitor dan melalui perangkat smartphone.

\subsection{Penentuan Alat dan Variabel Pengujian}

Aplikasi JMeter digunakan untuk melakukan pengujian dan setelahnya variabel pengujian ditentukan. Variabel pengujian (tabel 1) pada penelitian ini yaitu: (1) Kecepatan internet, (2) Thread (pengguna virtual), (3) Periode ramp-up. Periode rampup adalah jeda waktu yang dibutuhkan antar thread untuk mengakses website yang diuji. (4) Jumlah pengulangan (looping) untuk masing-masing thread (pengguna). Sedangkan untuk pengukuran hasil pengujian menggunakan error rate dan throughput serta jumlah sampel yang dapat diuji.

Tabel 1 Setting Variabel untuk beberapa Skenario Pengujian

\begin{tabular}{lcc}
\hline \multicolumn{3}{c}{ Setting variabel } \\
\hline Kode Pengujian & $\mathrm{A}$ & $\mathrm{B}$ \\
Kecepatan Internet & $18 \mathrm{Mbps}$ & $1.8 \mathrm{Mbps}$ \\
Jumlah Thread & 100 & 100 \\
Periode Ramp-up & 100 & 100 \\
Jumlah Pengulangan & 10 & 10 \\
\hline
\end{tabular}

Lebih lanjut lagi dari penentuan variabel tersebut, terdapat 2 skenario untuk mendapatkan 2 hasil pengujian yang dibagi oleh kode pengujian pada tabel 1. Kecepatan internet digunakan untuk melakukan simulasi pengujian dari sisi pengguna yang akan mengakses website Pemerintah Kota Pekalongan. Pada pengujian ini digunakan 2 (dua) jenis kecepatan internet yaitu: $18 \mathrm{Mbps}$ dan 1.8 Mbps (Gambar 5). Jumlah thread dibagi berdasarkan jenis kecepatan. Untuk masing-masing kecepatan akses internet jumlah thread sebanyak 100 (seratus) dengan periode ramp-up 100 (seratus) dan setiap thread melakukan pengulangan sebanyak 10 kali. Pengaturan tersebut dapat dilihat pada Gambar 4. Selanjutnya, diberikan waktu batasan jalannya pengujian selama 1 jam, dimana hal ini untuk memberikan batasan sampel uji coba yang bisa didapatkan selama pengujian berlangsung.

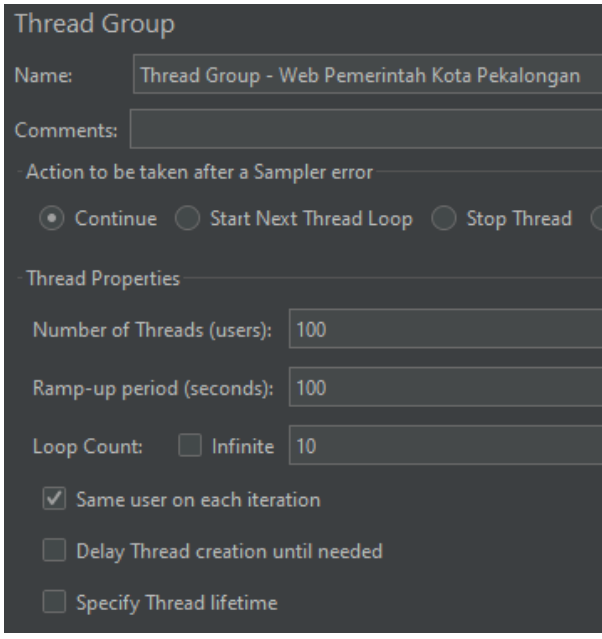

Gambar 4 Setting Thread

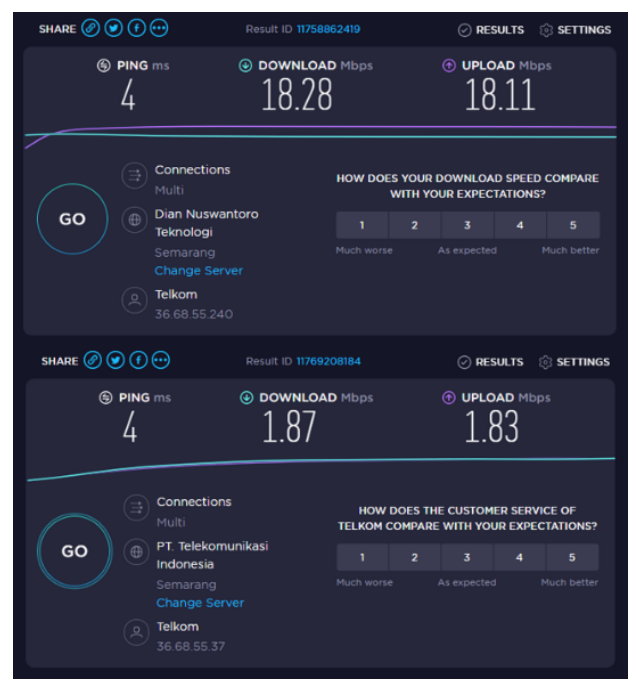

Gambar 5 Kecepatan internet yang Digunakan untuk Pengujian

Selain itu, spesifikasi hardware yang mengakses juga akan mempengaruhi hasil pengujian. Tabel 2 merupakan spesifikasi komputer yang digunakan untuk melakukan pengujian.

Tabel 2 Spesifikasi Hardware untuk Pengujian

\begin{tabular}{ll}
\hline Sistem Operasi & Windows 10 Pro 64 Bit \\
Processor & Intel Core i7-7700 @3.60 \\
& GHz \\
RAM & $16 \mathrm{~GB}$ \\
HDD & $1 \mathrm{~TB}$ \\
\hline
\end{tabular}

\subsection{Pengujian Performa Website}

Pengujian ini dimaksudkan untuk melakukan pengecekan beban akses yang dapat diterima oleh server dari alamat website Pemerintah Kota Pekalongan. Terdapat 3 hal yang diamati dari hasil 
pengujian, yaitu error rate, throughput dan jumlah sampel yang dapat diuji selama 1 jam. Error rate ini mengindikasikan server gagal menangani request dari pengguna untuk memuat website, semakin sedikit error rate semakin baik kinerja server. Sedangkan throughput merupakan kemampuan server untuk menangani jumlah maksimum pengguna yang mengunjungi situs web. Semakin tinggi nilai throughput maka semakin baik kinerja dari server di situs website tersebut. Tabel 3 merupakan hasil dari pengujian yang telah dilakukan.

Tabel 3 Hasil Pengujian Load Testing

\begin{tabular}{lcc}
\hline \multicolumn{3}{c}{ Setting Variabel } \\
\hline Kode Pengujian & $\mathrm{A}$ & $\mathrm{B}$ \\
Kecepatan Internet & $18 \mathrm{Mbps}$ & $1.8 \mathrm{Mbps}$ \\
\hline \multicolumn{3}{c}{ Hasil Pengujian } \\
\hline Jumlah Sampel & 1000 & 986 \\
Error Rate & $0.40 \%$ & $7.61 \%$ \\
Throughput & $528,7 /$ menit & $16.8 /$ menit \\
\hline
\end{tabular}

\subsection{Analisis Pengujian}

Dari hasil pengujian telah didapatkan perbandingan nilai yang secara signifikan berbeda antara 2 pengujian yang dilakukan dengan kecepatan internet yang berbeda. Dari hal tersebut dapat disimpulkan bahwa kecepatan internet berdampak pada server dalam melayani request dari pengguna. Semakin rendah kecepatan internet yang dimiliki pengguna, server akan mengirimkan data ke pengguna semakin lama juga. Hal ini akan mengakibatkan server memiliki beban kerja yang lebih lama dalam melayani satu pengguna dan mengakibatkan request untuk pengguna selanjutnya menjadi lebih lama.

Kemudian untuk jumlah sampel yang dapat diuji selama 1 jam pengujian, pada kecepatan akses 18 MBps jumlah sampel secara penuh dapat diuji yaitu 1000 sampel. Hal ini mengindikasikan bahwa semua sampel dari thread yang ada dapat berhasil melakukan request ke situs website. Nilai penuh 1000 ini didapatkan dari jumlah Thread sebanyak 100 dan setiap thread mengulang sebanyak 10 kali request akses. Sedangkan untuk kecepatan akses 1.8 MBps jumlah sampel yang didapatkan sebanyak 986 sampel. Hal ini menunjukkan bahwa dalam kurun waktu 1 jam request dari semua sampel yang ada, tidak semua request dari thread bisa dilayani.

Selanjutnya untuk analisis hasil pengujian error rate, pada kecepatan Kode Pengujian A memiliki persentase yang lebih rendah daripada Kode Pengujian B. Pada kecepatan 18 MBps, hasil pengujian menunjukkan nilai persentase $0.40 \%$ dari sampel yang ada. Nilai tersebut merepresentasikan request yang gagal untuk dilayani karena server tidak merespon permintaan dari pengguna. Sedangkan untuk pengujian pada akses kecepatan internet 1.8 MBps nilai persentasi error sebesar $7.61 \%$ dari sampel yang ada. Hal ini menunjukkan bahwa semakin besar kecepatan internet dari sisi pengguna maka semakin kecil kemungkinan dalam mendapatkan error saat mengakses website.

Berikutnya untuk nilai troughput dari kedua pengujian memiliki selisih nilai yang sangat besar. Untuk kecepatan akses 18 MBps, nilai troughput sebesar 528.7/menit yang berarti server dapat melayani 528.7 request dalam satu menit. Sedangkan pada kecepatan akses internet $1.8 \mathrm{MBps}$, nilai troughput sebesar 16.8/menit. Perbedaan nilai dari kedua pengujian tersebut sangat tinggi sekali. Jika terdapat pengguna yang mengakses melebihi nilai tersebut maka akan ada kemungkinan pengguna tidak dapat mengakses website. Dari hal tersebut kecepatan akses internet pengguna berperan penting dalam kecepatan server melayani request. Walaupun demikian, tidak bisa dipastikan semua pengguna memiliki kecepatan internet yang cepat dan stabil.

Selain itu untuk mengukur keragaman data, maka digunakan Standar Deviasi dari masing-masing hasil pengujian. Ketika dilakukan pengujian pada aplikasi JMeter dijalankan, Standar Deviasi ini akan tercatat dan menghitung secara otomatis oleh aplikasi tersebut. Contoh hasil pencatatan tersebut dapat dilihat pada Gambar 7. 


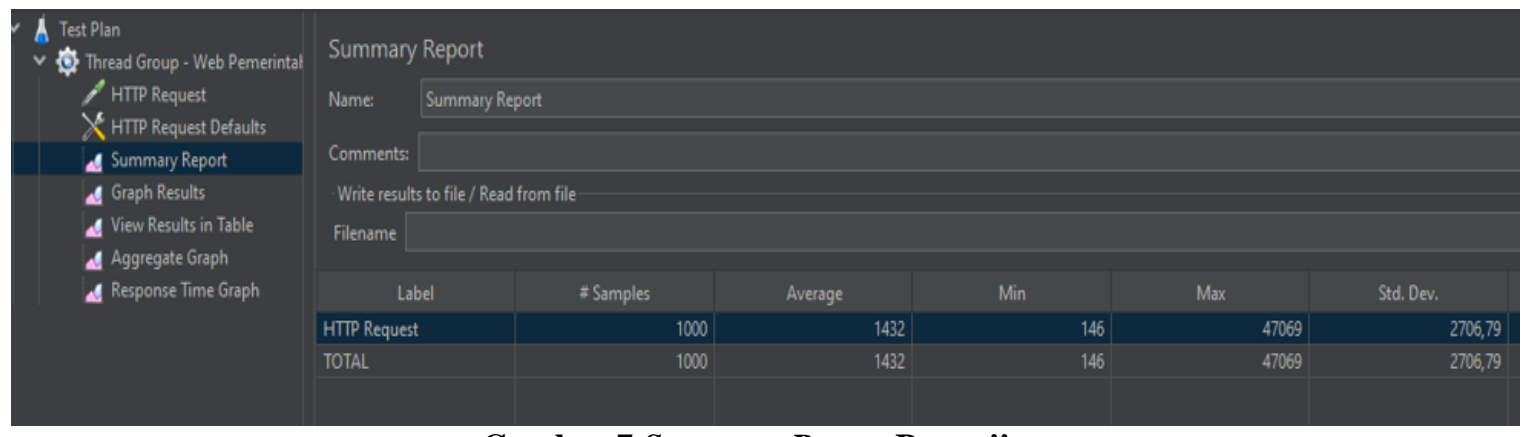

Gambar 7 Summary Report Pengujian

Dari kedua pengujian didapatkan nilai Standar Deviasi yang dapat dilihat pada tabel 4 berikut ini.

Tabel 4 Nilai Standar Deviasi Pengujian

\begin{tabular}{lcc}
\hline Kode Pengujian & A & B \\
Nilai Min & 146 & 475 \\
Nilai Max & 47069 & 3475162 \\
Nilai Mean & 1432 & 31124 \\
Nilai Standar Deviasi & 2706,79 & 154710,62 \\
\hline
\end{tabular}

Dari nilai Standar Deviasi yang ada pada tabel 4 dapat disimpulkan bahwa semua pengujian (Kode Pengujian A dan B) memiliki persebaran data yang bervariasi. Hal ini dibuktikan dengan nilai Standar Deviasi yang memiliki nilai lebih besar dari pada nilai Mean.

\section{SIMPULAN DAN SARAN}

\subsection{Simpulan}

Dari hasil pengujian dan analisis yang telah dilakukan, maka bagian yang perlu mendapatkan perhatian adalah seberapa sering pengguna dalam mengakses website. Jika dilihat dari hasil pengujian untuk kecepatan akses $1.8 \mathrm{MBps}$, server hanya dapat melayani sekitar 16.8 request setiap menit. Pada momen tertentu, bisa jadi website akan banyak dikunjungi oleh pengguna yang dapat mengakibatkan website down yang akhirnya tidak bisa diakses. Oleh karena itu diperlukan kajian lebih lanjut untuk mengetahui insight dari pengguna website Pemerintah Kota Pekalongan. Dari kajian tersebut dapat diketahui spesifikasi server yang diperlukan untuk mengakomodir website Pemerintah Kota Pekalongan.

\subsection{Saran}

Dari hasil penelitian yang telah dilakukan, Pemerintah Kota Pekalongan diharapkan untuk melakukan penyesuaian spesifikasi server, agar website utama Pemerintah Kota Pekalongan dapat lebih banyak melayani pengguna yang banyak ketika website diakses dalam waktu yang hampir bersamaan. Hal ini akan meminimalisir server down ketika lalu lintas website sedang tinggi.

\section{REFERENSI}

Abbas, R., Sultan, Z., \& Bhatti, D. S. (2017). Comparative Analysis of Automated Load Testing Tools: Apache JMeter, Microsoft Visual Studio (TFS), LoadRunner, Siege. IEEE.

Bhatti, S., \& Kumari, R. (2015). Comparative Study of Load Testing Tools. Int. J. Innov. Res. Comput. Commun. Eng., vol. 3, no. 3, 2334-2338.

Ghaffur, T. A., \& Nurkhamid. (2017). ANALISIS KUALITAS SISTEM INFORMASI KEGIATAN SEKOLAH BERBASIS MOBILE WEB DI SMK NEGERI 2 YOGYAKARTA. Elinvo (Electronics, Informatics, and Vocational Education), Volume 2, Nomor 1, Mei 2017, 94-101.

Hai-Jew, S. (2019). Designing Instruction For Open Sharing. Cham, Switzerland: Springer.

Lee-Jayaram, J. J., Berg, B. W., Sy, A., \& Hara, K. M. (2019). Emergent Themes for Instructional Design, 
Alpha and Beta Testing During a Faculty Development Course. the

Society for Simulation in Healthcare, 43-50.

Maulana, M. R., Susanto, E. B., \& Binabar,

S. W. (2020). ANALISA

PERFORMA WEBSITE

PEMERINTAH KABUPATEN

BATANG. IC-Tech.

MZ, Y. (2016). EVALUASI

PENGGUNAAN WEBSITE

UNIVERSITAS JANABADRA

DENGAN MENGGUNAKAN

METODE USABILITY TESTING.

Jurnal Informasi Interaktif Vol. 1 No.

1 Mei 2016, 34-43.

Patil, S. S., \& Joshi, S. D. (2012).

Identification of Performance

Improving Factors for Web

Application by Performance Testing. Int. J. Emerg. Technol. Adv. Eng., vol. 2, no. 8, 433-436.

Permatasari, M. A., Ma'ulfa, A. Y., Ilhami, N., Pratama, S. G., Astuti, S. R., \& Naufalita, N. W. (2020). Pengujian Aplikasi Menggunakan Metode Load Testing dengan Apache Jmeter pada Sistem Informasi Pertanian. Jurnal Sistem dan Teknologi Informasi, Vol 8, No. 1, Januari 2020, 135-139.

Putri, M. A., Hadi, H. N., \& Ramdani, F. (2017). Performance Testing Analysis on Web Application: Study Case Student Admission Web System. International Conference on Sustainable Information Engineering and Technology (SIET) , 1-5. 